"This accepted author manuscript is copyrighted and published by Elsevier. It is posted here by agreement between Elsevier and MTA. The definitive version of the text was subsequently published in [JOURNAL OF MOLECULAR STRUCTURE 1060:142-149 (2014) DOI 10.1016/j.molstruc.2013.12.025]. Available under license CC-BY-NC-ND."

\title{
The solvation and electrochemical behavior of copper acetylacetonate complexes in ionic liquids
}

\author{
Patrique Nunes ${ }^{a}$, Nóra V. Nagy ${ }^{b}$, Elisabete C.B.A. Alegria ${ }^{\mathrm{a}, \mathrm{c}}$, Armando J.L. Pombeiro ${ }^{\mathrm{a}}$, Isabel Correia ${ }^{\mathrm{a}, *}$ \\ ${ }^{a}$ Centro de Química Estrutural, Instituto Superior Técnico, University of Lisbon, Av. Rovisco Pais 1, 1049-001 Lisbon, Portugal \\ ${ }^{\mathrm{b}}$ Institute of Molecular Pharmacology, Research Centre for Natural Sciences, Hungarian Academy of Sciences, Pusztaszeri út 59-67, H-1025 Budapest, Hungary \\ 'Área Departamental de Engenharia Química, ISEL, R. Conselheiro Emídio Navarro, 1950-062 Lisbon, Portugal
}

\section{A B S T R A C T}

The behavior of copper(II) complexes of pentane-2,4-dione and 1,1,1,5,5,5-hexafluoro-2,4-pentanedione, $\left[\mathrm{Cu}(\mathrm{acac})_{2}\right](\mathbf{1})$ and $\left[\mathrm{Cu}(\mathrm{HFacac})_{2}\left(\mathrm{H}_{2} \mathrm{O}\right)\right](\mathbf{2})$, in ionic liquids and molecular organic solvents, was studied by spectroscopic and electrochemical techniques.

The electron paramagnetic resonance characterization (EPR) showed well-resolved spectra in most solvents. In general the EPR spectra of $\left[\mathrm{Cu}(\mathrm{acac})_{2}\right]$ show higher $\mathrm{g}_{\mathrm{z}}$ values and lower hyperfine coupling constants, $A_{\mathrm{z}}$, in ionic liquids than in organic solvents, in agreement with longer $\mathrm{Cu}-\mathrm{O}$ bond lengths and higher electron charge in the copper ion in the ionic liquids, suggesting coordination of the ionic liquid anions. For $\left[\mathrm{Cu}(\mathrm{HFacac})_{2}\left(\mathrm{H}_{2} \mathrm{O}\right)\right]$ the opposite was observed suggesting that in ionic liquids there is no coordination of the anions and that the complex is tetrahedrically distorted.

The redox properties of the $\mathrm{Cu}(\mathrm{II})$ complexes were investigated by cyclic voltammetry (CV) at a Pt electrode $(d=1 \mathrm{~mm})$, in bmimBF 4 and bmimNTf 2 ionic liquids and, for comparative purposes, in neat organic solvents. The neutral copper(II) complexes undergo irreversible reductions to $\mathrm{Cu}(\mathrm{I})$ and $\mathrm{Cu}(0)$ species in both ILs and common organic solvents $\left(\mathrm{CH}_{2} \mathrm{Cl}_{2}\right.$ or acetonitrile), but, in ILs, they are usually more easier to reduce (less cathodic reduction potential) than in the organic solvents. Moreover, $\mathbf{1}$ and $\mathbf{2}$ are easier to reduce in bmimNTf $f_{2}$ than in bmimBF$_{4}$ ionic liquid.

\section{Introduction}

Room temperature ionic liquids (ILs) are nowadays considered good alternatives to volatile organic solvents since they have appealing properties such as very low vapor pressure, high thermal stability, broad liquid temperature range, and high solvation power for a large range of organic compounds and catalysts, including Lewis acids [1]. The coordinating ability of an ionic liquid is a very important property particularly if a catalyst needs to coordinate a substrate for the catalytic reaction to occur. It has been shown that this depends mainly on the ionic liquid anion [2,3]. Several methods have been applied to evaluate the coordination ability of ionic liquid anions, the simplest one being the measurement of the absorption spectra of solvatochromic dyes. These are compounds that are sensitive to specific and/or non-specific interactions with the solvent. Their electronic absorption spectrum changes with the solvent's polarity and several probes have been used to evaluate interactions with ionic liquids, particularly the following transition metal complexes: $\left[\mathrm{Fe}(\text { phen })_{2}(\mathrm{CN})_{2}\right] \mathrm{ClO}_{4}[4]$,

\footnotetext{
* Corresponding author. Tel.: +351 218419268; fax: +351 21846445 . E-mail address: icorreia@ist.utl.pt (I. Correia).
}

$[\mathrm{Cu}(\mathrm{acac})($ tmen $)]\left[\mathrm{BPh}_{4}\right] \quad[2,3], \quad[\mathrm{Ni}(\mathrm{acac})(\mathrm{tmen})]\left[\mathrm{BPh}_{4}\right] \quad[5]$ and $\left[\mathrm{Mn}\left(\mathrm{NTf}_{2}\right)_{2}\right]$ [6], where phen $=1,10^{\prime}$-phenanthroline, acac $=$ acetylacetone, tmen $=\mathrm{N}, \mathrm{N}, \mathrm{N}^{\prime}, \mathrm{N}^{\prime}$-tetramethylethylenediamine, $\mathrm{BPh}_{4}=$ tetraphenylborate and $\mathrm{NTf}_{2}=$ bis(trifluoromethylsulfonyl)imide.

The lowest energy $d-d$ band of the square planar cation $[\mathrm{Cu}(\mathrm{acac})(\mathrm{tmen})]\left[\mathrm{BPh}_{4}\right]$ can be correlated with solvent donor numbers.[7] The shift in this band results from the $d$-orbital splitting of copper(II) when the complex becomes five or six coordinated. The results for ionic liquids showed that the spectroscopic shift was entirely independent of the nature of the cation and was only dependent on the anion [3]. The basicity order obtained for the studied IL anions was $\mathrm{PF}_{6}^{-}<\mathrm{NTf}_{2}^{-}<\mathrm{OTf}^{-}$. Our group reported on the structural characterization of vanadyl acetylacetonate in imidazolium room temperature ionic liquids, and showed that $\left[\mathrm{VO}(\mathrm{acac})_{2}\right]$ is solvatochromic in the selected ionic liquids and behaves as in molecular organic solvents, suggesting coordination of the ionic liquid anion in the solvents with higher coordinating ability [8]. The Lewis basicity order obtained for the reported ionic liquid anions was $\mathrm{PF}_{6}^{-}<\mathrm{NTf}_{2}^{-}<\mathrm{OTf}^{-} \approx \mathrm{MeCO}_{2}^{-}<\mathrm{MeSO}_{4}^{-}<\mathrm{BF}_{4}^{-} \approx \mathrm{N}(\mathrm{CN})_{2}^{-}<\mathrm{Me}_{2} \mathrm{PO}_{4}^{-}$, which is similar to the one obtained by Wasserscheid et al. [2]

$\mathrm{Bis}($ acetylacetonato $) \operatorname{copper}(\mathrm{II}),\left[\mathrm{Cu}(\mathrm{acac})_{2}\right]$, is a very common and stable transition metal complex. It is quite easy to prepare 
and shows simple magnetic and spectral properties. This paper reports an investigation on the effect of the solvent, in particular io nic liquids, on the visible absorption spectra and on the electron paramagnetic resonance (EPR) parameters of $\left[\mathrm{Cu}(\mathrm{acac})_{2}\right]$ and $\left[\mathrm{Cu}(\mathrm{HFacac})_{2}\left(\mathrm{H}_{2} \mathrm{O}\right)\right] \quad[\mathrm{HFacac}=1,1,1,5,5,5$-hexafluoro-2,4-pentanedione]. These complexes are soluble in a wide variety of organic solvents, in contrast to the copper halides, and therefore are good probes to evaluate the solvation ability of the ionic liquids. More over, its electrochemical behavior in selected ionic liquids is also studied. Neat organic solvents were used for comparison purposes.

The X-ray structure of [Cu(acac $\left.)_{2}\right][9-11]$ shows the two acetylacetonate molecules chelated to the copper ion by the four oxygen atoms, which are located on the plane. The symmetry of the molecule is $\mathrm{D}_{2 \mathrm{~h}}$ (sometimes approximated as $\mathrm{D}_{4 \mathrm{~h}}$ ), and all copper-oxygen distances are identical. On the other hand, the crystal structure of anhydrous $\left[\mathrm{Cu}(\mathrm{HFacac})_{2}\right]$ contains square-planar molecules with close intermolecular $\mathrm{Cu}-\mathrm{F}$ contacts $[12,13]$.

It is known that the bonding in a complex can be strongly influenced by the nature of the surroundings, namely the solvent. EPR is a helpful spectroscopic tool for the evaluation of the coordination

in paramagnetic metal complexes. Copper(II) has an unpaired electron in a $d^{9}$ electronic configuration with a nuclear spin of $3 / 2$ (for the two stable isotopes ${ }^{63} \mathrm{Cu}$ and ${ }^{65} \mathrm{Cu}$ ). The spin Hamiltonian parameters - $g$ value and hyperfine coupling constant, $A$ - are strongly influenced by the ligand donor atoms. Moreover, coordination of solvent molecules or anions in the apical positions of square planar copper complexes, increases the $\mathrm{Cu}$-donor atom bond length, decreasing the $A_{z}$ value and increasing the $g_{z}$ value [14].

In this report we present the structural characterization of $\left[\mathrm{Cu}(\mathrm{acac})_{2}\right]$ and $\left[\mathrm{Cu}(\mathrm{HFacac})_{2}\right]$ by Vis and EPR spectroscopies, and electrochemistry, in organic solvents and ionic liquids. Well-resolved EPR spectra were obtained in most solvents.

\section{Results and discussion}

\subsection{Characterization of the ionic liquids}

The ionic liquids chosen for this study are constituted by the ions shown in Scheme 1. They are mainly derived from bmim ${ }^{+}$ (1-butyl-3-methylimidazolium) with different anions. For the sake of cation comparison bmpyNTf ${ }_{2}$ (bmpy $^{+}=1$-butyl-3-methylpyrrolidinium) was also used. The preparation and spectral data for the ionic liquids have been described elsewhere.[8,15] The procedure used in the preparation and/or purification is able to afford colorless liquids, suitable for spectroscopic studies. The analytic characterization showed the absence of impurities, such as residual chloride, which could change the solvation properties. Before using, these ILs were dried for at least $48 \mathrm{~h}$ in vacuum at $50{ }^{\circ} \mathrm{C}$. The water content was measured by Karl Fischer coulometer analysis. For hydrophobic ILs the values did not exceed $400 \mathrm{ppm}$, but for the most hygroscopic they can reach $3100 \mathrm{ppm}$, which in terms of water concentration corresponds to $0.18 \mathrm{M}$.

\subsection{Characterization of the copper(II) complexes}

The copper(II) complexes were prepared according to literature procedures [16] and their characterization (elemental analysis and FTIR) confirmed the formulation. The copper bis-hexafluoroacetylacetonate complex may be obtained as the dark blue-violet anhydrous, the blue-green $\left[\mathrm{Cu}(\mathrm{HFacac})_{2}\left(\mathrm{H}_{2} \mathrm{O}\right)\right]$ or the yellow-green $\left[\mathrm{Cu}(\mathrm{HFacac})_{2}\left(\mathrm{H}_{2} \mathrm{O}\right)_{2}\right]$ complex [13,17]. The assignment of the number of water molecules for the prepared complex is not straightforward: the color (yellow-green) suggests the presence of two water molecules, however the carbon content $(24.3 \%)$ fits the $\left[\mathrm{Cu}(\mathrm{HFacac})_{2}\left(\mathrm{H}_{2} \mathrm{O}\right)\right]$ formulation (theoretical value $24.3 \%$ ), which was the one used throughout the work.

The electronic absorption spectra of the complexes were measured in organic solvents and the obtained spectra are included in Supporting Information (SI). Being a $d^{9}$ metal ion, copper is subject to Jan-Teller distortion. In square planar or octahedral complexes the unpaired electron occupies the $d_{\mathrm{x} 2-\mathrm{y} 2}$ orbital, which has its lobes pointing directly to the equatorial ligands, along the $x$ and $y$ axes of the molecule. The absorption spectra of the compounds shows 2 or 3 bands in the Vis region (in some cases they are overlapped) which can be attributed to the promotion of the electrons in the lower energy orbitals to the hole in $d_{\mathrm{x} 2-\mathrm{y} 2}$ orbital of the copper(II) ion. We tried to correlate the low energy absorption maximum with the Kamlet-Taft [18-21] (KT) solvent parameters. Although in most cases the fitting parameters were not satisfactory, there were clear correlations with $\beta$, the hydrogen bond basicity, for $\left[\mathrm{Cu}(\mathrm{HFacac})_{2}\right]$, which is known for becoming 5 or 6-coordinated in donating solvents:

$\lambda_{\max }=680 \pm 5+36 \pm 9 \times \beta \quad\left(r^{2}=0.70\right)$

In ionic liquids no clear correlation with the KT solvent parameters was observed. This suggests that either the solvation process depends on several parameters (and as the number of solvents used was limited, it was not possible to obtain any correlation with more than one parameter) or that the presence of different amounts of residual water in the ionic liquids affects its solvation properties, and therefore the KT parameters, which has been shown by other authors [22-24]. Fig. 1 shows the absorption spectra obtained for complex $\left[\mathrm{Cu}(\mathrm{HFacac})_{2}\left(\mathrm{H}_{2} \mathrm{O}\right)\right]$ in selected ionic liquids. $\left[\mathrm{Cu}(\mathrm{acac})_{2}\right]$ is only soluble in the ILs containing the anions with the higher coordinating power, e.g. $\mathrm{N}(\mathrm{CN})_{2}^{-}$[8]. The fluorinated complex is sparingly soluble in a wide range of ILs. Therefore, the most solvatochromic complex in the selected ILs is $\left[\mathrm{Cu}(\mathrm{HFacac})_{2}\left(\mathrm{H}_{2} \mathrm{O}\right)\right]$, for which a variation of $\mathrm{ca} .190 \mathrm{~nm}$ in the position of the absorption maximum for the lower energy band was observed. Table 1 presents the data, which is included in graphical form in the supporting information.

\subsection{EPR in organic solvents}

The EPR spectra of $\left[\mathrm{Cu}(\mathrm{acac})_{2}\right](\mathbf{1})$ in organic solvents were mea sured both at room temperature and $77 \mathrm{~K}$, while those of $[\mathrm{Cu}(\mathrm{HFa}-$ cac $)_{2}\left(\mathrm{H}_{2} \mathrm{O}\right)$ ] (2) were measured only at $77 \mathrm{~K}$. All spectra were simulated using a program developed by Rockenbauer and Korecz [25]. The EPR spectra measured at room temperature for $\left[\mathrm{Cu}(\mathrm{acac})_{2}\right]$ (see $\mathrm{SI}$ ) present the expected four-line pattern and the line widths change with the nuclear quantum number $\left(m_{I}\right)$, with the high field line being narrower and more intense than the lower field lines. In some solvents the isotropic spectra from the monomer is superimposed on an isotropic singlet $(\Delta \mathrm{Ms}= \pm 1)$ from copper clusters (e.g. in DMSO). The inclusion of this "background" signal in the simulation improved the quality of the fit. Table 2 presents the spin Hamiltonian parameters obtained. The values are in good agreement with data from the literature [26] and it was possible to correlate the spin Hamiltonian isotropic parameters ( $g_{\text {iso }}$ and $A_{\text {iso }}$ ) with the solvent basicity $(\beta)$ (see SI):

$g_{\text {iso }}=2.1206 \pm 0.005+0.030 \pm 0.008 \times \beta\left(r^{2}=0.757\right)$

$A_{\text {iso }}=79 \pm 5-25 \pm 9 \times \beta\left(r^{2}=0.651\right)$

In general, the higher the solvent basicity, the longer the $\mathrm{Cu}-\mathrm{O}$ bonds and therefore the higher the electron density in the copper ion, which leads to an increase in the $g$-value and a decrease in the hyperfine coupling constant, $A$, as expected.[14]. 


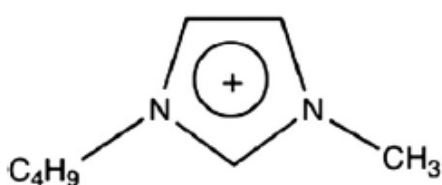

bmim $^{+}$<smiles>O=S(=O)([N-]S(=O)(=O)C(F)(F)F)C(F)(F)F</smiles>

NTf $_{2}$ -

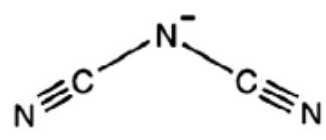

$\mathrm{N}(\mathrm{CN})_{2}^{-}$

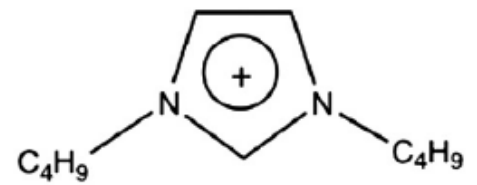

bbim $^{+}$<smiles>F[B-](F)(F)F</smiles>

$\mathrm{BF}_{4}^{-}$<smiles>COS(=O)(=O)O[Na]</smiles>

$\mathrm{MeSO}_{4}{ }^{-}$

$\mathrm{PF}_{6}$ -

$\mathrm{Me}_{2} \mathrm{PO}_{4}{ }^{-}$<smiles>C[N+]1(C)CCCC1</smiles>

bmpy $^{+}$<smiles>FP(F)(F)(F)(F)(F)F</smiles><smiles>COP(=O)([O-])OC</smiles><smiles>O=S(=O)([O-])C(F)(F)F</smiles>

OTf<smiles>CC(=O)[O-]</smiles>

OAc ${ }^{-}$<smiles></smiles>

1<smiles></smiles>

2

Scheme 1 . 


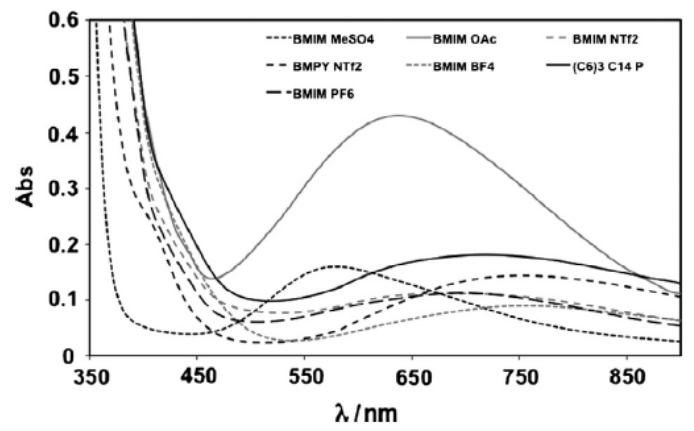

Fig. 1. Absorption spectra of $\left[\mathrm{Cu}(\mathrm{HFacac})_{2}\left(\mathrm{H}_{2} \mathrm{O}\right)\right](\mathrm{C} \sim 3 \mathrm{mM})$ in selected ionic liquids.

The anisotropic EPR spectra obtained at $77 \mathrm{~K}$ are better resolved and more informative. Most of the EPR spectra were simulated assuming rhombic symmetry for the $\mathrm{g}$ and A tensors. The line shape was described as Gaussian (in most cases) and the line widths as dependent, i.e. the line width changes with the orientation (parallel or antiparallel direction) and with the nuclear quantum number. Figures with the simulated and experimental spectra are included in the supporting information section.

For both complexes it was possible to observe hyperfine coupling in the perpendicular region, in most organic solvents. Also, the low-field peak $\left(m_{I}=-3 / 2 \|\right)$ is split in two, due to the two $\mathrm{Cu}$ isotopes $\left({ }^{63} \mathrm{Cu}\right.$ and ${ }^{65} \mathrm{Cu}$, with natural abundances of $69 \%$ and
Table 1

Wavelength $(\mathrm{nm})$ of the lowest energy absorption band for both complexes in organic solvents and ionic liquids.

\begin{tabular}{lll}
\hline Solvent/complex & {$\left[\mathrm{Cu}(\mathrm{acac})_{2}\right]$} & {$\left[\mathrm{Cu}(\mathrm{HFacac})_{2}\right]$} \\
\hline DMSO & 651 & - \\
DMF & 642 & 710 \\
MeOH & 639 & - \\
Pyridine & 663 & 695 \\
$\mathrm{THF}$ & 620 & 708 \\
$\mathrm{CHCl}$ & 657 & 687 \\
Acetone & - & 694 \\
1 -BuOH & - & 712 \\
$\mathrm{CH}{ }_{3} \mathrm{CN}$ & - & 693 \\
EtOH & - & 708 \\
Ethyl acetate & - & 691 \\
$\mathrm{H}_{2} \mathrm{O}$ & - & - \\
$\mathrm{BmimN}(\mathrm{CN})_{2}$ & 671 & - \\
$\mathrm{BmimOAc}_{\text {BmimBF }}$ & 659 & 641 \\
BmimMeSO $_{4}$ & 706 & 770 \\
BmimPF $_{6}$ & 651 & 582 \\
BmimNTf $_{2}$ & - & 701 \\
BmpyNTf $_{2}$ & - & 698 \\
\hline
\end{tabular}

$31 \%$, respectively), which have slightly different nuclear gyromagnetic ratios and the same nuclear spin (3/2). The low $A_{z}$ value found for $\left[\mathrm{Cu}(\mathrm{acac})_{2}\right]$ in pyridine, confirms coordination of this solvent in the apical position. The isotropic Hamiltonian parameters calculated using the formulae $A_{\text {iso }}=\left(A_{\mathrm{x}}+A_{\mathrm{y}}+A_{\mathrm{z}}\right) / 3$ and $g_{\text {iso }}=\left(g_{\mathrm{x}}+g_{\mathrm{y}}+-\right.$ $\left.g_{z}\right) / 3$ agree reasonably well with the ones determined at room temperature. The EPR spectra measured for $\left[\mathrm{Cu}(\mathrm{HFacac})_{2}\left(\mathrm{H}_{2} \mathrm{O}\right)\right]$

(2) in organic solvents show, in general, lower $A_{z}$ values and higher

Table 2

Spin Hamiltonian parameters of the copper complexes. Obtained by simulation of the spectra.

\begin{tabular}{|c|c|c|c|c|c|c|c|c|c|}
\hline Solvent & $g_{x}$ & $g_{y}$ & $g_{z}$ & $g_{\text {iso }}$ & $A_{\mathrm{x}}$ & $A_{\mathrm{y}}$ & $A_{\mathrm{z}}$ & $A_{\text {iso }}$ & $g_{\mathrm{z}} / A_{\mathrm{z}}(\mathrm{cm})$ \\
\hline \multicolumn{10}{|l|}{$\left[\mathrm{Cu}(\mathrm{acac})_{2}\right]$} \\
\hline $\mathrm{MeOH}$ & & & & 2.139 & & & & 64.2 & \\
\hline $\mathrm{CHCl}_{3}$ & & & & 2.123 & & & & 76.9 & \\
\hline DMF & & & & 2.138 & & & & 65.3 & \\
\hline $\mathrm{CHCl}_{3}$ & 2.0603 & 2.0465 & 2.2845 & 2.130 & 18.4 & 16.3 & 170.4 & 68.4 & 134 \\
\hline Pyridine & 2.0573 & 2.0789 & 2.3014 & 2.146 & 0 & 9.7 & 154.8 & 54.8 & 149 \\
\hline $\mathrm{MeOH}$ & 2.0514 & & 2.2901 & 2.131 & 5.2 & & 175.2 & 61.8 & 131 \\
\hline \multirow[t]{2}{*}{$\mathrm{bmimBF}_{4}$} & 2.0638 & & 2.2876 & & 23.1 & & 162.9 & & 140 \\
\hline & 2.0630 & & 2.3136 & & 8.8 & & 155.5 & & 149 \\
\hline $\mathrm{bmimMeSO}_{3}$ & 2.0557 & 2.0619 & 2.3064 & & 13.9 & 13.1 & 164.9 & & 142 \\
\hline \multirow[t]{2}{*}{$\mathrm{bmimMeSO}_{4}$} & 2.0485 & 2.0937 & 2.2840 & & 20.1 & 69.7 & 161.3 & & 142 \\
\hline & 2.0570 & 2.0664 & 2.3144 & & 13.4 & 20.5 & 152.0 & & 152 \\
\hline \multicolumn{10}{|l|}{$\left[\mathrm{Cu}(\mathrm{HFaCac})_{2}\right]$} \\
\hline $\mathrm{CHCl}_{3}$ & 2.0730 & & 2.3563 & & 0 & & 141.2 & & 167 \\
\hline bmimOAc & 2.0577 & 2.0420 & 2.3204 & & 22.3 & 17.3 & 171.0 & & 136 \\
\hline $\mathrm{bmimBF}_{4}$ & 2.0696 & 2.0623 & 2.3381 & & 0 & 11.1 & 152.2 & & 154 \\
\hline & 2.0683 & 2.0623 & 2.3309 & & 0 & 12.6 & 156.4 & & 149 \\
\hline \multirow{2}{*}{ bmimNTf $_{2}$} & 2.0691 & 2.0602 & 2.3364 & & 0 & 10.0 & 152.7 & & 153 \\
\hline & 2.0606 & 2.0555 & 2.3194 & & 10.0 & 8.5 & 162.5 & & 143 \\
\hline \multirow[t]{2}{*}{ bmpyNTf $_{2}$} & 2.0692 & 2.0619 & 2.3250 & & 0.0 & 11.1 & 171.5 & & 154 \\
\hline & 2.0707 & 2.0669 & 2.3851 & & 16.9 & 2.0 & 140.2 & & 170 \\
\hline
\end{tabular}

$g_{z}$ values, than the $\left[\mathrm{Cu}(\mathrm{acac})_{2}\right](\mathbf{1})$ complex, in agreement with longer $\mathrm{Cu}-\mathrm{O}$ bonds, and higher ability to coordinate solvent molecules in the apical positions. This is due to the high electronegativity of the fluoro atoms, which decreases the electron density at the copper ion. Table 2 also includes an empirical parameter, developed by Sakaguchi and Addison [27] known as the tetrahedral distortion index, which can be obtained by dividing $g_{z}$ by $A_{z}\left(\right.$ in $\mathrm{cm}^{-1}$ ). Values within $100-135 \mathrm{~cm}$ suggest a square planar geometry and the larger the ratio the higher the tetrahedral distortion. This can be represented in a plot of $A_{\mathrm{z}} v s . g_{\mathrm{z}}$, which is shown in Fig. 2, for the two complexes in ionic liquids and molecular organic solvents, and for complexes with $\mathrm{O}_{4}$ coordination (taken from Ref. [27]). Complexes with high tetrahedral distortion are the ones shown on the right bottom side of the graph. It is clear that the fluorinated complex 2 shows higher tetrahedral distortion than $\left[\mathrm{Cu}(\mathrm{acac})_{2}\right]$, in most solvents.

\subsection{EPR in ionic liquids}

The X-band EPR spectra of the two complexes in a series of ionic liquids containing mostly imidazolium cations and anions with different coordinating abilities, were measured at $77 \mathrm{~K}$. Figs. 3 and 4 exhibit the EPR spectra of these complexes obtained in the ILs 


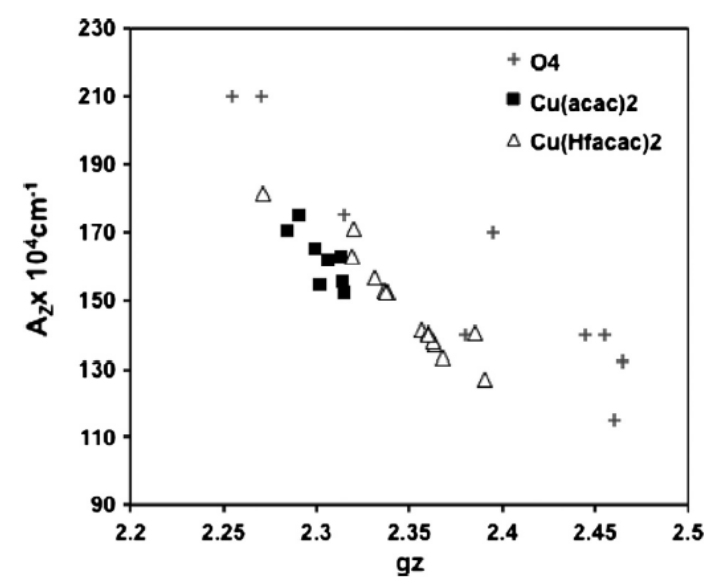

Fig. 2. $A_{2}$ vs. $g_{z}$ correlation for the $\left[\mathrm{Cu}(\mathrm{acac})_{2}\right](\mathbf{1})$ and $\left[\mathrm{Cu}(\mathrm{HFacac})_{2}\left(\mathrm{H}_{2} \mathrm{O}\right)\right](2$ complexes in organic solvents and ionic liquids and for copper complexes with $\mathrm{O}_{4}$ donor groups.[24].

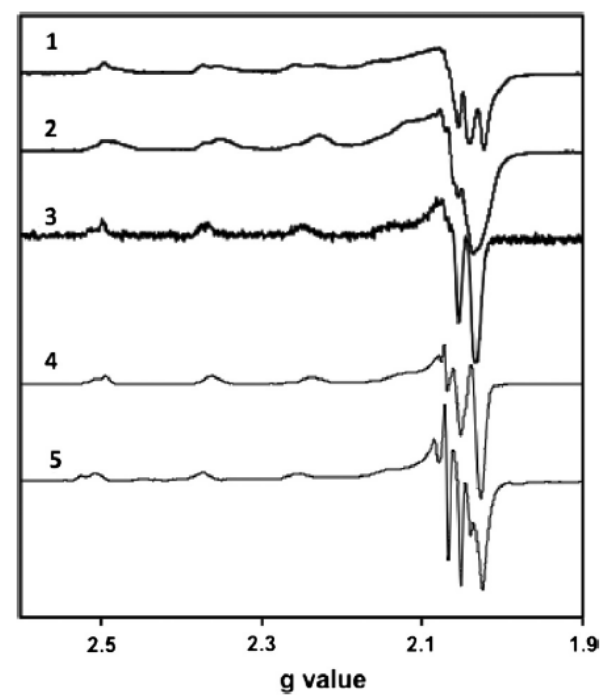

Fig. 3. EPR spectra of $\left[\mathrm{Cu}(\mathrm{acac})_{2}\right](\mathbf{1})(\sim 3 \mathrm{mM})$ obtained at $77 \mathrm{~K}$ in ionic liquids. 1 bmimMeSO $4,2-$ bmimBF$_{4}, 3-$ bmimMeSO$_{3}, 4-\operatorname{bmimN}(\mathrm{CN})_{2}$ and $5-$ bmimOAc.

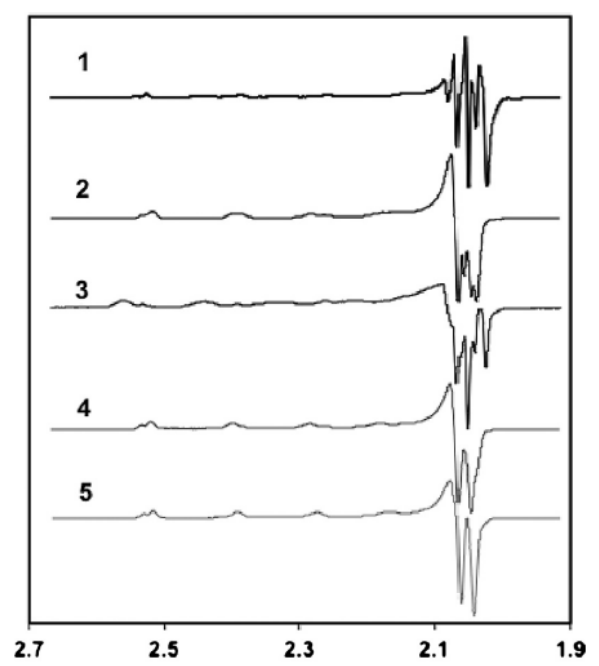

g value and Fig. 5 exhibits an example of an experimental and a simulated spectrum: $\left[\mathrm{Cu}(\mathrm{acac})_{2}\right]$ in bmimOAc (others are included in $\mathrm{SI}$ ). The EPR spectra of $\left[\mathrm{Cu}(\mathrm{acac})_{2}\right]$ observed in $\mathrm{bmimBF}_{4}$ and bmimMeSO show the presence of two species. Its parameters were obtained by simulation and the species with $A_{\mathrm{z}} \sim 152 \times 10^{-4} \mathrm{~cm}^{-1}$ probably corresponds to the square planar $\left[\mathrm{Cu}(\mathrm{acac})_{2}\right]$ complex and the other to a solvolysis species. For $\left[\mathrm{Cu}(\mathrm{HFacac})_{2}\left(\mathrm{H}_{2} \mathrm{O}\right)\right](2)$, two species were also observed in bmimNTf ${ }_{2}$ and bmpyNTf ${ }_{2}$, and we assign the species with $A_{\mathrm{z}} \sim 152 \times 10^{-4} \mathrm{~cm}^{-1}$ to the square planar complex, but the other species must correspond to different types of complexes since its parameters are very different. However, with the available data we cannot propose an assignment.

The spectra of $\left[\mathrm{Cu}(\mathrm{HFacac})_{2}\left(\mathrm{H}_{2} \mathrm{O}\right)\right](2)$ show the low field splitting due to the two copper isotopes in most ILs; they were simulated as rhombic; and they show hyperfine splitting in the perpendicular region of the spectra. For complex $\mathbf{1}$, if we exclude the spectrum in pyridine, in which the low $A_{\mathrm{z}}$ and high $g_{\mathrm{z}}$ values suggest coordination of the solvent in the apical positions, we can observe higher $g_{z}$ and lower $A_{z}$ values in ionic liquids than in organic solvents. This is consistent with longer $\mathrm{Cu}-\mathrm{O}$ bonds, and higher electron charge in the copper ion in the ionic liquids, suggesting coordination of the ionic liquid anions. For the fluorinated

temperature, were carried out and a broad reduction wave was observed at $c a .-1.9 \mathrm{~V} v s$. $\mathrm{FcH} / \mathrm{FCH}^{+}$, probably due to the reduction of the bmim $^{+}$cation to carbene, that could be followed by dealkylation and dimerization reactions [28]. Upon scan reversal, following the cathodic process, a new oxidation wave was observed at $E_{\mathrm{p}}=0.5 \mathrm{~V} v s . \mathrm{FcH} / \mathrm{FCH}^{+}$, corresponding to the oxidation of a species formed at the cathodic process. No oxidation wave was observed up to $1.8 \mathrm{~V}$, when starting the cyclic voltamogram with the anodic scan. This behavior shows that bmimBF 4 and bmimNTf ${ }_{2}$ are electrochemically stable in a wide potential range, suitable for the investigation of complexes $\mathbf{1}$ and $\mathbf{2}$, in accordance with previous observations [29].

Complexes $\left[\mathrm{Cu}(\mathrm{acac})_{2}\right] \mathbf{1}$ and $\left[\mathrm{Cu}(\mathrm{HFacac})_{2}\left(\mathrm{H}_{2} \mathrm{O}\right)\right] 2$ exhibit by cyclic voltammetry, at a platinum electrode and room temperature (Table 3), one first irreversible reduction process (wave $\mathbf{I}^{\text {red }}$ ) at ${ }^{\mathrm{I}} E_{\mathrm{p}}^{\mathrm{red}}=-0.99$ or -0.73 vs. $\mathrm{FcH} / \mathrm{FCH}^{+}$, for $\mathbf{1}$ or $\mathbf{2}$, respectively, in bmimNTf $f_{2}$ (Fig. 6 for 2 ). In bmimBF 4 , the wave occurs at ${ }^{\mathrm{I}} E_{\mathrm{p}}^{\text {red }}=-1.08$ or $-0.79 \mathrm{~V} v$ s. $\mathrm{FcH} / \mathrm{FcH}^{+}$, for $\mathbf{1}$ or $\mathbf{2}$, respectively. This first cathodic wave is followed, at a lower potential, by a second irreversible one (wave II $^{\text {red }}$ ) at " $E_{\mathrm{p}}^{\text {red }}=-1.37$ or $-1.26 \mathrm{~V} v \mathrm{~s}$. FCH/ $\mathrm{FCH}^{+}$for $\mathbf{1}$ or $\mathbf{2}$, respectively, in bmimNTf ${ }_{2}$. In bmimBF 4 , this second reduction wave is observed at ${ }^{1} E_{\mathrm{p}}^{\text {red }}=-1.57$ or $-1.33 \mathrm{~V} v s$. $\mathrm{FcH} / \mathrm{FcH}^{+}$ for $\mathbf{1}$ or $\mathbf{2}$, respectively. For complexes $\mathbf{1}$ and $\mathbf{2}$ the two cathodic processes ( $\mathbf{I}^{\text {red }}$ and $\mathbf{I I}^{\text {red }}$ ) are believed (see also below, the behavior in an organic solvent) to correspond to the $\mathrm{Cu}^{\mathrm{II}} \rightarrow \mathrm{Cu}^{\mathrm{I}}$ and $\mathrm{Cu}^{\mathrm{I}} \rightarrow-$ $\mathrm{Cu}^{0}$ reductions. Electrochemical reduction of simple $\mathrm{Cu}^{\text {II }}$ halide

salts in mixed (20:1, v:v) bmimPF $/ \mathrm{bmimCl}_{6}$ [30], in 1-butyl-3methylimidazolium bromide (bmimBr) [31], or in chloroaluminate ionic liquids (on glassy carbon or tungsten electrodes) [32] is also known to occur in two distinct single-electron cathodic waves.

Upon scan reversal following the cathodic processes, anodic irreversible waves are detected (range of $c a$. -0.5 to $0.8 \mathrm{~V} v s$. $\mathrm{FcH} / \mathrm{FcH}^{+}$) on account of the oxidation of reduced species formed in the former processes (see Fig. 6 for complex 2 in bmimNtf where an anodic dissolution wave of deposited copper formed at the reduction process is clearly observed).

The two complexes show a higher resistance to reduction (reductions occur at more cathodic potentials) in bmimBF 4 relatively to bmimNTf $f_{2}$, probably due to the considerable coordination power of the $\mathrm{BF}_{4}^{-}$anion, higher than that of $\mathrm{NTf}_{2}^{-}$(lower basicity), which may increase the electron richness at the metal center.

The higher (less cathodic) reduction potential values observed for $\mathbf{2}$ in comparison with those of $\mathbf{1}$, in both ILs, is consistent with the weaker electron-donor character of the fluorinated HFacac ligand in comparison with acac. In fact, the value of the electrochemical Lever $E_{\mathrm{L}}$ parameter (a measure of the electron-donor 
Fig. 4. EPR spectra of $\left[\mathrm{Cu}(\mathrm{HFacac})_{2}\left(\mathrm{H}_{2} \mathrm{O}\right)\right](2)(\sim 3 \mathrm{mM})$ obtained at $77 \mathrm{~K}$ in ionic liquids. 1 - bmimOAc, 2 - bmimNTf, 3 - bmpyNTf $_{2}, 4-$ bmimBF$_{4}$ and 5 - bmimPF 6 .

complex 2 the opposite is observed. While in molecular organic solvents the $A_{\mathrm{z}}$ values vary between 127 and $141 \times 10^{-4} \mathrm{~cm}^{-1}$, in ionic liquids the $A_{\mathrm{z}}$ values are higher than $152 \times 10^{-4} \mathrm{~cm}^{-1}$ (excluding one of the species found in bmpyNTf ${ }_{2}$ ). This suggests that in ionic liquids there is no coordination of the anions and that the complex is tetrahedrically distorted. This is easily observed in Fig. 2 since most points from the data obtained with $\left[\mathrm{Cu}(\mathrm{HFacac})_{2}\right.$ ($\left.\mathrm{H}_{2} \mathrm{O}\right)$ ] fall in the lower right corner.

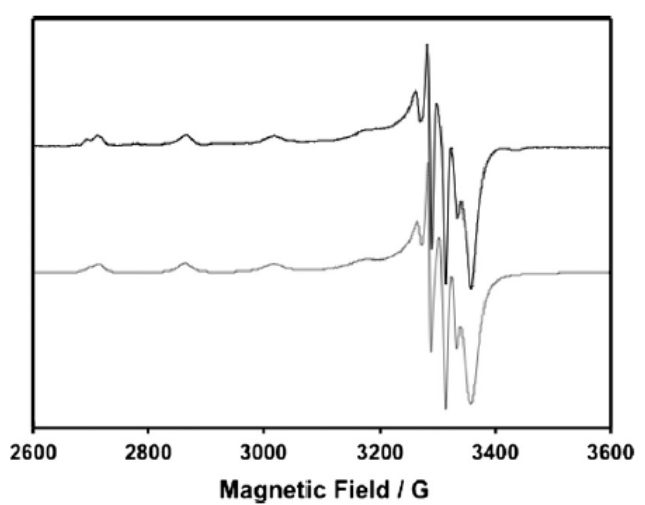

Fig. 5. Experimental and simulated EPR spectra of $\left[\mathrm{Cu}(\mathrm{acac})_{2}\right](\mathbf{1})$ in bmimOAc Gray line - experimental spectrum and black line - simulated spectrum.

\subsection{Electrochemical characterization of the complexes}

Cyclic voltammograms of the pure ILs bmimBF 4 and bmimNTf using a platinum disk working electrode $(d=1 \mathrm{~mm})$, at room

Table 3

Cyclic voltammetric data ${ }^{\mathrm{a}}$ for $\left[\mathrm{Cu}(\mathrm{acac})_{2}\right] \mathbf{1}$ and $\left[\mathrm{Cu}(\mathrm{Hfacac})_{2}\right] 2$.

\begin{tabular}{lll}
\hline Solvent & ${ }^{\mathrm{I}} E_{\mathrm{p}}^{\text {red }}\left(\mathrm{I}^{\text {red }}\right)$ & ${ }^{\mathrm{II}} E_{\mathrm{p}}^{\text {red }}\left(\mathrm{II}^{\text {red }}\right)$ \\
\hline$\left[\mathrm{Cu}(\mathrm{acac})_{2}\right] \mathbf{1}$ & & \\
bmimNTf & & -1.37 \\
bmimBim $_{4}$ & -0.99 & -1.57 \\
$\mathrm{CH}_{2} \mathrm{Cl}_{2}$ & -1.08 & - \\
$\mathrm{NCMe}$ & -1.61 & - \\
{$\left[\mathrm{Cu}(\mathrm{HFacac})_{2}\right] \mathbf{2}$} & -1.57 & \\
bmimNTf $_{2}$ & & -1.26 \\
bmimBimF $_{4}$ & -0.73 & -1.33 \\
$\mathrm{CH}_{2} \mathrm{Cl}_{2}$ & -0.79 & -1.56 \\
$\mathrm{NCMe}$ & -0.74 & -
\end{tabular}

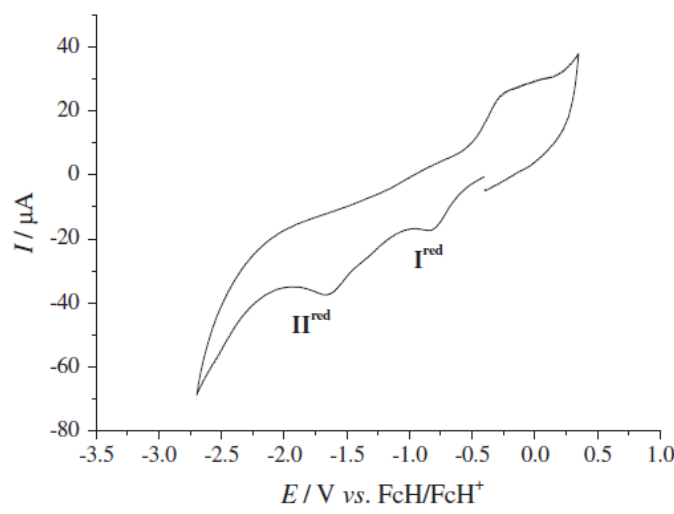




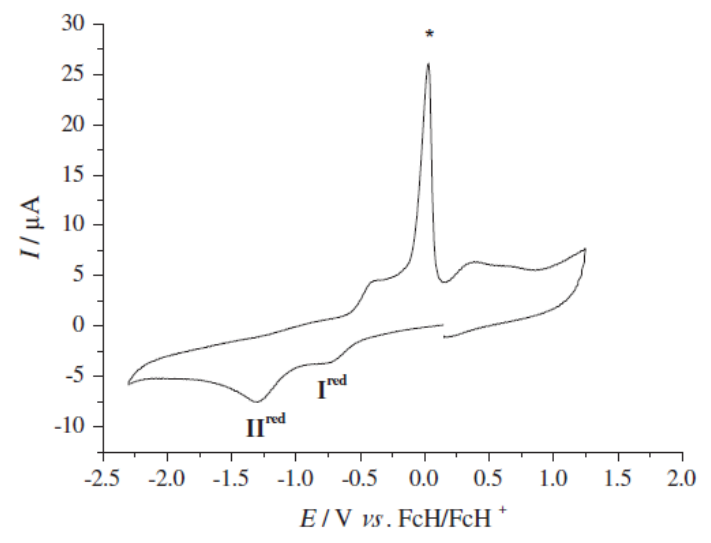

Fig. 6. Cyclic voltammogram of complex $\left[\mathrm{Cu}(\mathrm{HFacac})_{2}\left(\mathrm{H}_{2} \mathrm{O}\right)\right]$ (2), at a Pt electrode, initiated by the cathodic sweep, in bmimNTf $\left(v=200 \mathrm{mV} \mathrm{s}^{-1}\right)$. [Comple 2] = $20 \mathrm{mM}$. * This wave corresponds to anodic dissolution of deposited copper.

ability of a ligand [33-38], the stronger that character the lower $E_{\mathrm{L}}$ ) for HFacac $\left(E_{\mathrm{L}}=0.17 \mathrm{~V}\right)$ [35] is higher than that for acac $\left(E_{\mathrm{L}}=\right.$ $-0.08 \mathrm{~V})$ [35].

The redox properties of $\mathbf{1}$ and $\mathbf{2}$, for comparative purposes, have also been investigated by cyclic voltammetry, in an organic sol vent, i.e., in $0.2 \mathrm{M}\left[{ }^{n} \mathrm{Bu}_{4} \mathrm{~N}\right]\left[\mathrm{BF}_{4}\right] /\left(\mathrm{CH}_{2} \mathrm{Cl}_{2}\right.$ or acetonitrile) solutions, and the measured redox potentials (in $V$ vs. $\mathrm{FcH} / \mathrm{FcH}^{+}$) are also gi-

ven in Table 3. They show one irreversible reduction process (wave $I^{\text {red }}$, Fig. 7 for 2 , in $\left.\mathrm{CH}_{2} \mathrm{Cl}_{2}\right)$ at ${ }^{\mathrm{I}} \mathrm{E}_{\mathrm{p}}^{\text {red }}=-1.61$ or $-0.74 \mathrm{~V}$ vs. $\mathrm{FcH} / \mathrm{FCH}^{+}$ for 1 or 2 , in $\mathrm{CH}_{2} \mathrm{Cl}_{2}$ (and at ${ }^{\mathrm{l}} \mathrm{E}_{\mathrm{p}}^{\mathrm{red}}=-1.57$ or $-0.92 \mathrm{~V} v \mathrm{~s}$. $\mathrm{FcH} / \mathrm{FCH}^{+}$for $\mathbf{1}$ or $\mathbf{2}$, in acetonitrile). Moreover, a second irreversible reduction process is observed at $\mathrm{ca}$. $-1.56 \mathrm{~V}$ vs. $\mathrm{FcH} / \mathrm{FcH}^{+}$for complex 2, in $\mathrm{CH}_{2} \mathrm{Cl}_{2}$. For complex 1 (in $\mathrm{CH}_{2} \mathrm{Cl}_{2}$ and NCMe, see Fig. 8) and for 2 (in $\mathrm{NCMe}$ ), the second cathodic waves are detected, conceivably being buried under the solvent/electrolyte discharge, in view of their expected very low reduction potentials. Two distinct cathodic waves attributed to the successive $\mathrm{Cu}^{\mathrm{II}} \rightarrow \mathrm{Cu}^{\mathrm{I}}$ and $\mathrm{Cu}^{\mathrm{I}} \rightarrow \mathrm{Cu}^{0}$ reductions were also observed in organic solvents for other copper(II) $\beta$ diketonate chelates [39-41] and for copper(II) complexes with 3 (ortho-substituted phenylhydrazo)pentane-2,4-diones [42].

The acetonitrile solution of complex 1 exhibits two irreversible oxidation waves (see Fig. 8) at the potential values of 1.09 and $1.55 \mathrm{~V}$ vs. $\mathrm{FcH} / \mathrm{FcH}^{+}$, the former conceivably concerning the $\mathrm{Cu}^{\mathrm{II}} \rightarrow$ $\mathrm{Cu}^{\text {III }}$ oxidation. Metal-centred $\mathrm{Cu}^{\text {II }} \rightarrow \mathrm{Cu}^{\text {III }}$ oxidations have been observed in organic solvents for other copper(II) complexes, such as $\left[(\right.$ py $\left.) \mathrm{Cu}\left(\mu_{2}-\mathrm{OOCCH}_{2} \mathrm{C}_{6} \mathrm{H}_{4} \mathrm{R}\right)_{4} \mathrm{Cu}(\mathrm{py})\right] \quad\left(\mathrm{R}=\right.$ para $-\mathrm{NO}_{2}, \quad$ para $-\mathrm{CH}_{3}$ $\mathrm{py}=$ pyridine $)[43]$ and $[\mathrm{Cu}($ salacopd $)] \mathrm{Cl}_{2}[$ salacopd $=14$-membered macrocyclic 2,4,9,11-tetramethyl-6,7-13,14-dibenzo-1,5,8,12-tetraaza-3,10-bis(salicylidene)cyclotetradeca-1,4,8,11-tetraene] [44].

anion in the solvation of the complexes. Overall, the EPR spectra obtained for $\left[\mathrm{Cu}(\mathrm{acac})_{2}\right]$ indicate longer $\mathrm{Cu}-\mathrm{O}$ bonds, and higher electron charge in the copper center in the ionic liquids, suggesting coordination of the ionic liquid anions. For $\left[\mathrm{Cu}(\mathrm{HFacac})_{2}\left(\mathrm{H}_{2} \mathrm{O}\right)\right]$ the higher $A_{\mathrm{z}}$ values observed in ILs, when compared to organic solvents suggest that in ionic liquids there is no coordination of the anions and that the complex is simply tetrahedrically distorted.

The electrochemical studies show that the neutral copper complexes are easier to reduce in bmimNTf $_{2}$ than in bmimBF 4 , probably due to the considerable coordinating ability of the $\mathrm{BF}_{4}^{-}$anion or to the lower viscosity of the ionic liquid containing $\mathrm{NTf}_{2}^{-}$. In both ILs and common organic solvents $\left(\mathrm{CH}_{2} \mathrm{Cl}_{2}\right.$ or $\left.\mathrm{NCMe}\right)$ the complexes undergo irreversible reductions to $\mathrm{Cu}(\mathrm{I})$ and $\mathrm{Cu}(0)$ species, but, in ILs, they are usually easier to reduce (less cathodic reduction potentials) than in the organic solvents. For $\mathrm{Cu}(\mathrm{HFacac})_{2} \mathrm{H}_{2} \mathrm{O}$ this is in agreement with the EPR observations, since they also point to lower electronic charge at the $\mathrm{Cu}$ center in ILs. Other explanations may include stabilization of the reduced species by interaction with the ionic liquid cation.

\section{Experimental}

4.1. Materials and reagents
Fig. 7. Cyclic voltammogram of complex $\left[\mathrm{Cu}(\mathrm{HFacac})_{2}\left(\mathrm{H}_{2} \mathrm{O}\right)\right] 2$ using a Pt electrode, initiated by the cathodic sweep, in $0.2 \mathrm{M}\left[{ }^{n} \mathrm{Bu}_{4} \mathrm{~N}\right]\left[\mathrm{BF}_{4}\right] / \mathrm{CH}_{2} \mathrm{Cl}_{2}$ solution $\left(v=200 \mathrm{mV} \mathrm{s}^{-1}\right)$. [Complex 2] $=6.2 \mathrm{mM}$

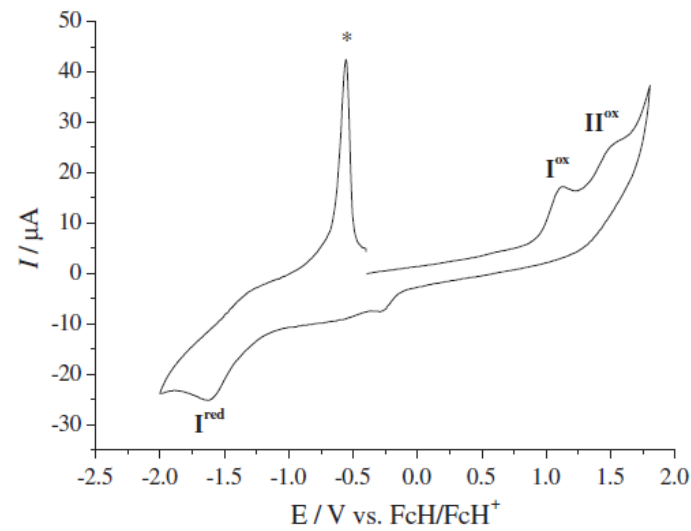

Fig. 8. Cyclic voltammogram of complex $\left[\mathrm{Cu}(\mathrm{acac})_{2}\right]$ (1) using a Pt electrode, initiated by the anodic sweep, in $0.2 \mathrm{M}\left[{ }^{n} \mathrm{Bu}_{4} \mathrm{~N}\right]\left[\mathrm{BF}_{4}\right] /$ acetonitrile solution $(v=200$ $\mathrm{mV} \mathrm{s}^{-1}$ ). [Complex 1] $=5.7 \mathrm{mM}$. * This wave corresponds to anodic dissolution of deposited copper.

txhaustive controlled-potential electrolyses to measure the number of electrons involved in each redox process was not possible due to fast electrode passivation.

Overall, we can conclude that both complexes are easier to reduce in bmimNTf ${ }_{2}$, than in bmimBF$_{4}$, and are easier to reduce in these ionic liquids than in common organic solvents $\left(\mathrm{CH}_{2} \mathrm{Cl}_{2}\right.$, acetonitrile). To explain these observations it would be necessary to determine diffusion coefficients and solubility of the complexes in the ionic liquids, however, this was outside the scope of our work. Nonetheless, low viscosity and high solubility facilitate reduction of the complexes in ionic liquids, which accounts for the easier reduction observed in bmimBF 4 , when compared to bmimNTf ${ }_{2}$, since the viscosity of bmimNTf b $_{2}$ is lower than that of

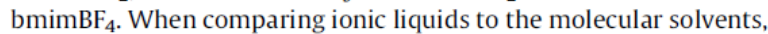
other factors should be responsible for the observations made. The species with lower oxidation states are stabilized in ionic liquids, which might be due to interaction with the ionic liquid cation.

\section{Conclusions}

The structural characterization done by spectroscopic and electrochemical techniques evidences the influence of the ionic liquid

EPR spectra were recorded either at $77 \mathrm{~K}$ (on glassy samples made by freezing solutions in liquid nitrogen) or at room temperature using a Bruker ESP 300E X-band spectrometer.

\subsection{Cyclic voltammetry}

All manipulations were performed under an atmosphere of nitrogen using standard vacuum and inert-gas flow techniques. The organic solvents, acetonitrile and dichloromethane, were purified by standard procedures and freshly distilled immediately prior to use. Solutions of five different concentrations of the $\mathrm{Cu}$ (II) complex $2(1,5,10,20$ and $40 \mathrm{mM})$ in bmimNTf 2 and bmimBF bionic $_{4}$ liquids, were studied by cyclic voltammetry. Poor solubility was observed for complex $\mathbf{1}$ in both ionic liquids. The electrochemical experiments were performed on an EG\&G PAR 273A potentiostat/ galvanostat connected to a personal computer through a GPIB interface. All experiments were carried in a glass CV cell that was continuously purged with nitrogen. Cyclic voltammograms were obtained in $0.2 \mathrm{M}\left[{ }^{n} \mathrm{Bu}_{4} \mathrm{~N}\right]\left[\mathrm{BF}_{4}\right] / \mathrm{CH}_{2} \mathrm{Cl}_{2}$ (or acetonitrile) solution, and in bmimNTf or bmimBF$_{4}$ ionic liquids, using a platinum disk working electrode $(d=1 \mathrm{~mm})$, at room temperature. A Luggin capillary connected to a silver wire pseudo-reference electrode was used to control the working electrode potential, and a Pt wire was employed as the counter-electrode. The redox potentials of 
All chemicals used were of analytical reagent grade. 1-Methylimidazole was purchased from Acros Organics and distilled over potassium hydroxide; 1-chlorobutane was purchased from Acros Organics and distilled over phosphorus pentoxide. Lithium bis(trifluoromethylsulfonyl)imide [ $\left.\mathrm{Li}\left(\mathrm{NTf}_{2}\right)\right]$ and lithium trifluoromethanesulfonate [Li(OTf)] were purchased from Apollo Scientific and used as received. All syntheses and sample preparations were performed under anaerobic conditions using standard Schlenk techniques. The preparation and spectral data of the ionic liquids have been described elsewhere. The water content of the ionic liquids was measured by Karl Fischer titration, after drying for $48 \mathrm{~h}$ in vacuum at $50{ }^{\circ} \mathrm{C}$. The values were: $360 \mathrm{ppm}$ for bmimNTf $145 \mathrm{ppm}$ for bbimNTf $2,280 \mathrm{ppm}$ for bmpyNTf $2,1370 \mathrm{ppm}$ for bmimOTf, $1570 \mathrm{ppm}$ for bmimBF $4,150 \mathrm{ppm}$ for bmimPF, $1200 \mathrm{ppm}$ for bmimMe $\mathrm{PO}_{4}, 1600 \mathrm{ppm}$ for bmimOAc, $400 \mathrm{ppm}$ for bmim$\mathrm{MeSO}_{4}$ and 3100 for bmimN $(\mathrm{CN})_{2}$.

\subsection{Synthesis of the complexes}

$\left[\mathrm{Cu}(\mathrm{acac})_{2}\right]-$ The complex was synthesized by mixing $0.27 \mathrm{~mL}$ of acetylacetone $(2.6 \mathrm{mmol})$ with $0.32 \mathrm{~g}$ of $\mathrm{CuSO}_{4} \cdot 5 \mathrm{H}_{2} \mathrm{O}(1.3 \mathrm{mmol})$ in cold water containing a few drops of ammonia (27\%). The obtained precipitate was filtered and washed with acetone and wate and dried under vacuum. Dark blue needles were obtained afte recrystallization from toluene. Yield: $58.5 \%$ (0.199 g). Anal. Calcd. For $\mathrm{C}_{10} \mathrm{H}_{14} \mathrm{O}_{4} \mathrm{Cu}$ : C, 45.9; $\mathrm{H}, 5.4$. Found: $\mathrm{C}, 45.9 ; \mathrm{H}, 5.4$. IR ( $\mathrm{KBr}$ disk, $\left.\mathrm{cm}^{-1}\right): 3466[\mathrm{~V}(\mathrm{O}-\mathrm{H})], 2987$ and 2922 [V $(\mathrm{C}-\mathrm{H})_{\text {aliff }}, 1581$ [V $(\mathrm{C}=0)], 1535[v(\mathrm{C}=\mathrm{C})], 456[\mathrm{v}(\mathrm{Cu}-\mathrm{O})]$.

$\left[\mathrm{Cu}(\mathrm{HFacac})_{2}\left(\mathrm{H}_{2} \mathrm{O}\right)\right]$ - The complex was prepared according to published procedures.[16] Yellow-green crystals were obtained. Anal. Calcd. For $\mathrm{C}_{10} \mathrm{H}_{2} \mathrm{O}_{4} \mathrm{~F}_{12} \mathrm{Cu} \cdot \mathrm{H}_{2} \mathrm{O}$ : C, 24.3; $\mathrm{H}, 0.8$. Found: $\mathrm{C}$ $24.4 ; \mathrm{H},<2.0$. IR ( $\mathrm{KBr}$ disk, $\left.\mathrm{cm}^{-1}\right): 3479$ [V $\left.(\mathrm{O}-\mathrm{H})\right], 2927$ and 2858 [ $\left.\mathrm{V}(\mathrm{C}-\mathrm{H})_{\text {alif }}\right], 1648[\mathrm{v}(\mathrm{C}=\mathrm{O})], 1535[\mathrm{v}(\mathrm{C}=\mathrm{C})], 1262$ and $1151[\mathrm{~V}(\mathrm{C}-\mathrm{F})]$.

\subsection{Instruments}

${ }^{1} \mathrm{H}$ NMR spectra were recorded using a Bruker 300 or $400 \mathrm{MHz}$ spectrometer. UV-Vis spectra were recorded using a Perkin-Elmer UV-visible Lambda 35 spectrophotometer and the temperature was controlled with a Peltier controller from Perkin-Elmer. The

[21] T. Yokoyama, R.W. Taft, M.J. Kamlet, J. Am. Chem. Soc. 98 (1976) 3233-3237. [22] S.N. Baker, G.A. Baker, F.V. Bright, Green Chem. 4 (2002) 165-169.

[23] S. Trivedi, N.I. Malek, K. Behera, S. Pandey, J. Phys. Chem. B 114 (2010) 8118 8125 .

24] N.D. Khupse, A. Kumar, J. Phys. Chem. B 115 (2010) 711-718.

[25] A. Rockenbauer, L. Korecz, Appl. Magn. Reson. 10 (1996) 29-43.

[26] I. Adato, I. Eliezer, J. Chem. Phys. 54 (1971) 1472-1476.

27] U. Sakaguchi, A.W. Addison, J. Chem. Soc. Dalton (1979) 600-608.

28] P. He, H.T. Liu, Z.Y. Li, Y. Liu, X.D. Xu, J.H. Li, Langmuir 20 (2004) 10260-10267.

29] S. Eugenio, C.M. Rangel, R. Vilar, S. Quaresma, Electrochim. Acta 56 (2011) 10347-10352.

[30] L. Yu, H. Sun, J. He, D. Wang, X. Jin, X. Hu, G.Z. Chen, Electrochem. Commun, 9 (2007) 1374-1381.

[31] E.P. Grishina, A.M. Pimenova, N.O. Kudryakova, L.M. Ramenskaya, Russ. J. Electrochem. 48 (2012) 1166-1170.

[32] F. Endres, ChemPhysChem 3 (2002) 144-154.

[33] A.B.P. Lever, Inorg. Chem. 30 (1991) 1980-1985.

34] A.B.P. Lever, Inorg. 29 (1990) 1271-1285.

[35] http://www.chem.yorku.ca/profs/lever/elparameter98.htm. the complexes were determined by cyclic voltammetry in the presence of ferrocene as the internal standard, and their values are given relative to $\left[\mathrm{Fe}\left(\eta^{5}-\mathrm{C}_{5} \mathrm{H}_{5}\right)_{2}\right]^{0 /+}\left(\mathrm{FcH} / \mathrm{FCH}^{+}\right)$redox couple. For their conversion to the SCE reference, one can use the following oxidation potentials of $\mathrm{FcH} / \mathrm{FCH}^{+}: E_{1 / 2}^{\mathrm{ox}}=0.525 \mathrm{~V}$ vs. SCE (in $\mathrm{CH}_{2} \mathrm{Cl}_{2}$ ) or $0.45 \mathrm{~V}$ vs. SCE (in acetonitrile) $[45,46]$.

\section{Acknowledgments}

The authors would like to thank Fundação para a Ciência e Tecnologia for funding through program CIÊNCIA 2007 and Projects PTDC/QUI-QUI/098516/2008, PTDC/QUI-QUI/102150/2008 and Pest-OE/QUI/UI0100/2013.

\section{Appendix A. Supplementary material}

Supplementary data associated with this article can be found, in the online version, at http://dx.doi.org/10.1016/j.molstruc.2013. 12.025 .

\section{References}

[1] T. Welton, Chem. Rev. 99 (1999) 2071-2083.

[2] P. Wasserscheid, C.M. Gordon, C. Hilgers, M.J. Muldoon, I.R. Dunkin, Chem. Commun. (2001). 1700-1700.

3] M.J. Muldoon, C.M. Gordon, L.R. Dunkin, J. Chem. Soc. Perk. T 2 (2001) 433-435.

[4] R. Lungwitz, M. Friedrich, W. Linert, S. Spange, New J. Chem. 32 (2008) $1493-$ 1499.

[5] J. Bartosik, A.V. Mudring, Phys. Chem. Chem. Phys. 12 (2010) 4005-4011.

[6] S. Pitula, A.V. Mudring, Phys. Chem. Chem. Phys. 12 (2010) 7056-7063.

[7] I. Persson, Pure Appl. Chem. 58 (1986) 1153-1161.

8] A. Mota, J.P. Hallett, M.L. Kuznetsov, I. Correia, Phys. Chem. Chem. Phys. 13 2011) 15094-15102.

[9] P.C. Lebrun, W.D. Lyon, H.A. Kuska, J. Cryst. Spectrosc. 16 (1986) 889-893.

(10] Z.A. Starikova, E.A. Shugam, Zh. Strukt, Khim. (English Translation) 10 (1969).

[11] H. Golchoubian, Asian J. Chem. 20 (2008) 5.

12] S.A. Gromilov, I.A. Baidina, P.A. Stabnikov, G.V. Romanenko, J. Struct. Chem 45 (2004) $476-481$

[13] A.W. Maverick, F.R. Fronczek, E.F. Maverick, D.R. Billodeaux, Z.T. Cygan, R.A. Isovitsch, Inorg. Chem. 41 (2002) 6488-6492.

[14] W.M. Ames, S.C. Larsen, J. Phys. Chem. A 113 (2009) 4305-4312.

[15] L. Cammarata, S.G. Kazarian, P.A. Salter, T. Welton, Phys. Chem. Chem. Phys. 3 2001) 5192-5200.

[16] J.A. Bertrand, R.I. Kaplan, Inorg. Chem. 5 (1966). 489-8..

18] M.J. Kamlet, J.L. Abboud, R.W. Taft, J. Am. Chem. Soc. 99 (1977) 6027-6038.

19] MJ. Kamlet, R.W. Taft, J. Am. Chem. Soc. 98 (1976) 377-383.

20l RW. Taft, MJ. Kamlet, J. Am. Chem. Soc. 98 (1976) $2886-2894$.

[36] M.F.C. Guedes da Silva, A.J.L. Pombeiro, Electrochim. Acta 82 (2012) 478-484.

[37] A.J.L. Pombeiro, Eur. J. Inorg. Chem. (2007) 1473.

[38] A.J.L. Pombeiro, J. Organomet. Chem. 690 (2005) 6021.

39] W. Mickler, A. Mönner, E. Uhlemann, Collect. Czech. Chem. Commun. 63 (1998) 1963 .

[40] D. Mich, C. Mihailciuc, Analele UniversitǎŃii din Bucuresti-Chimie, Anul XV (serie noua), I.

[41] D. Mich, C. Mihailciuc, Analele UniversitǎŃNii din Bucuresti-Chimie, Anul XV (serie noua), II 49-52.

[42] M.N. Kopylovich, A.C.C. Nunes, K.T. Mahmudov, M. Haukka, T.C.O. Mac Leod, L.M.D.R.S. Martins, M.L. Kuznetsov, A.J.L. Pombeiro, Dalton Trans. 40 (2011) 2822-2836.

[43] M. Iqbal, S. Ali, N. Muhammad, M. Sohail, Polyhedron 57 (2013) 83-93.

[44] K. Jeyasubramanian, S.A. Samath, S. Thambidurai, R. Murugesan, S.K. Ramalingam, Transit Metal Chem 20 (1995) 76-80.

[45] A.J.L. Pombeiro, M.F.C.G. da Silva, M.A.N.D.A. Lemos, Coordin. Chem. Rev. 219 (2001) 53-80.

[46] M.E.N.P.R.A. Silva, A.J.L. Pombeiro, J.J.R.F. Dasilva, R. Herrmann, N. Deus, T.J. Castilho, M.F.C.G. Silva, J. Organomet. Chem. 421 (1991) 75-90. 